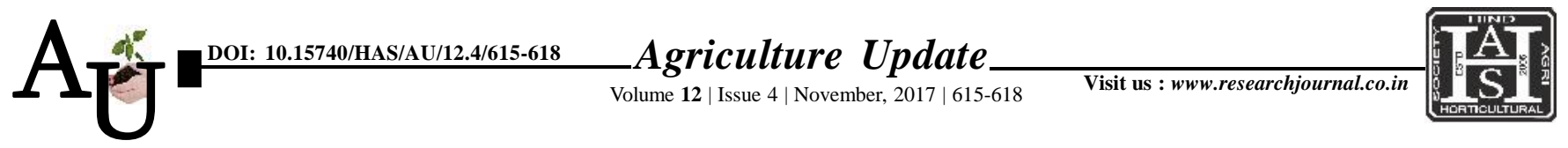

— e ISSN-0976-6847

\title{
Research Article: An analysis of marketing pattern followed by the soybean growers of north Karnataka
}

\section{S.K. JAMANAL AND SYED SADAQATH}

Article Chronicle :

Received :

22.08.2017;

Revised :

10.09.2017;

Accepted :

27.09.2017

KEY WoRds:

Marketing pattern, Soybean growers, Production technology

Author for correspondence :

S.K. JAMANAL Department of Agricultural Extension Education, College of Agriculture, University of Agricultural Sciences, DHARWAD (KARNATAKA) INDIA

Email:sidjamanal@ gmail.com

See end of the article for authors' affiliations
SUMMARY : The present investigation was undertaken to find out the marketing pattern followed by the soybean growers. The study covered 15 villages from 3 taluks of Dharwad district to form a sample of 150 respondents. A pre-tested structured interview schedule was used to collect the data from the respondents by personal interview method. The results indicated that, 56.00 per cent of the respondents sell their produce immediately after the harvest if the prices are favourable, followed by 54.66 per cent of the farmers collect the price information from their relatives, friends and neighbours who visit the market, 47.33 per cent farmers sold their produce in local market at village level, 44.00 per cent of the respondents store their produce for short time to get better price if the prices are less at the time of harvest, whereas only 22.66 per cent of the respondents had followed grading of the produce.

How to cite this article : Jamanal, S.K. and Sadaqath, Syed (2017). An analysis of marketing pattern followed by the soybean growers of north Karnataka. Agric. Update, 12(4): 615-618; DOI : 10.15740/HAS/AU/12.4/615618. 